\title{
Project Implementation of the Micro Hydroelectric Roncador
}

\author{
J. A. A. Polli ${ }^{1}$, G. M. Alves ${ }^{1}$, R. C. Betini ${ }^{1}$, P. C. Fritzen ${ }^{1}$ \\ ${ }^{1}$ Department of Electrical Engineering \\ Federal Technological University of Paraná \\ Campus of Curitiba - Av. Sete de Setembro, 3165, 80230-340 Curitiba (Brazil) \\ Phone/Fax number: 005541 8456-3957/, e-mail: jpolli@alunos.utfpr.edu.br, gilbertomanoel@yahoo.com.br, \\ betini@utfpr.edu.br, pcfritzen@gmail.com
}

\begin{abstract}
.
The city of Bocaiúva do Sul/PR and the Federal Technological University of Paraná (UTFPR) signed an agreement for the creation of an Environmental Education Center in the city. This agreement includes the reactivation of Roncador hydroelectric micro-station, to generate electricity through four different types of turbines, which will serve as a teaching laboratory for the academic community. This work aimed to carry out studies for the implementation of the Roncador hydroelectric micro-station project, which is disabled since 1950 . For the study, a review of the literature was performed and field work was carried out to analyse the existing and all necessary structures to implement the hydroelectric micro-station. After analysis it was found that it is a run-of-river hydroelectric, where part of the existing structure could be reused, however, there was a need for full reconstruction of some structures. The gross head extent was 14.8 $\mathrm{m}$ with a flow rate of $0.450 \mathrm{~m} 3 / \mathrm{s}$ and a power of $47 \mathrm{~kW}$.
\end{abstract}

\section{Key words}

Implantation, Hydroelectric micro power plant.

\section{Introduction}

The access to electricity was one of the important factors for the world to reach the current level of technological and social development. According the site Portal Brazil (2014), the electricity demand in the country raised $3.6 \%$ in 2013. There are suitable alternatives to meet the increase in domestic demand, one of them is Distributed Generation (DG). Dias (2005) defines DG as any generating source with production for local or nearby loads, fed without transport through transmission networks.

The use of micro hydropower station has not yet become an attractive business in the domestic market, one reason is the complexity of implementation and the cost of generation compared to other energy sources. Nevertheless, the micro station are potentially important for the generation of electricity, especially for isolated systems and perspective of access to energy in all the country.

Currently the term sustainable development or sustainability has been widely reported, defined as one that meets the needs of present generations without affecting the ability of future generations to also meet their needs. Major changes are needed for the energy sector to become sustainable, as the policies that redirect the choices of technologies and investments in the sector, to reduce environmental impacts.

The search for alternative sources of energy is planned today, including those carried out by small hydropower (SHP), which are excellent renewable energy production systems (Alves, 2007), attractive for studies on the implementation of small and micro hydroelectric plants.

\section{Classification of Hydroelectric Plants}

According to Eletrobrás and DNAEE (1985), there are two basic arrangements to consider in a micro hydropower (SHP): run-of-river or accumulation centre with daily regulation reservoir.

According to Schreiber (1977), a run-of-river hydroelectric does not have a significant accumulation of basin of water and whose production is inconstant, depending on the river flow oscillation. Eletrobrás and DNAEE (1985) state that the volume of the reservoir created is despised and the adduction system is designed to conduct the required discharge to the power that meets peak demand. 
In the case of accumulation, Eletrobrás and DNAEE (1985) state that this type of plant is used when the minimum river flow is not sufficient to meet the required discharge to supply the maximum consumer market demand and must resort the reservoir contribution.

\section{Structure of Micro Hydroelectric Plant}

The main structures to be studied for a micro hydroelectric plant are: dam, spillway, water intake, adduction system (adduction channel and pipe in low pressure), equilibrium chimney / standpipe, penstock, power house and tailrace. Hydroelectric plants can also be classified according to their power and the project fall. Eletrobrás (1982), suggests a classification for small hydropower (SHP) shown in table (I). in the reservoir, avoiding the risk of the water level reaches the crest of the reservoir or dam.

According to ELETROBRÁS \& DNAEE (1985), the width of the spillway it may be calculated according to equation (1).

$$
b=\frac{Q}{1,7 \times h^{3 / 2}}
$$

Where $b$ is width of spillway [m], $\mathrm{Q}$ is the maximum flow $\left[\mathrm{m}^{3} / \mathrm{s}\right]$ and $\mathrm{h}$ is height of the water depth $[\mathrm{m}]$.

The existing spillway at hydroelectric is incorporated by the dam, the structure has a length of $7.08 \mathrm{~m}$, crest of $0.54 \mathrm{~m}$ and a water depth measuring of $0.47 \mathrm{~m}$, the structure is in working condition. Considering the maximum flow rate of $2.08 \mathrm{~m}^{3} / \mathrm{s}$ with the measured value of water depth $0.47 \mathrm{~m}$, the minimum length value calculated from equation (1) is $3.80 \mathrm{~m}$.

Table I. - Small hydroelectric rating as the power and project fall

\begin{tabular}{|c|c|c|c|c|}
\hline \multirow{2}{*}{$\begin{array}{c}\text { CLASSIFICATION OF } \\
\text { PLANTS }\end{array}$} & POWER $-\mathrm{P}(\mathbf{k W})$ & \multicolumn{3}{|c|}{ PROJECT FALL $-\mathrm{H}(\mathrm{m})$} \\
\cline { 3 - 5 } & & LOW & AVERAGE & HIGH \\
\hline MICRO & $\mathrm{P}<100$ & $\mathrm{H}<15$ & $15<\mathrm{H}<50$ & $\mathrm{H}>50$ \\
\hline MINI & $100<\mathrm{P}<1.000$ & $\mathrm{H}<20$ & $20<\mathrm{H}<100$ & $\mathrm{H}>100$ \\
\hline SMALL & $1.000<\mathrm{P}<30.000$ & $\mathrm{H}<25$ & $25<\mathrm{H}<130$ & $\mathrm{H}>130$ \\
\hline
\end{tabular}

\section{Micro Hydroelectric Plant Roncador}

The Roncador Hydroelectric Power Plant is located in the municipality of Bocaiúva do Sul, at Paraná State, $44.6 \mathrm{~km}$ far from Curitiba. According to the Instituto das Águas do Paraná, the operation start of the Roncador plant occurred in 1953, consisting of two generators, one $200 \mathrm{~kW}$ and other $30 \mathrm{~kW}$, both using the Francis type turbine. The Roncador hydroelectric is classified as run-of-river hydroelectric micro-station, according to the specifications of Eletrobrás and DNAEE (1985), with a gross head $\left(\mathrm{H}_{\mathrm{b}}\right)$ of $14.8 \mathrm{~m}$ with a maximum measured flow rate of 2.08 $\mathrm{m}^{3} / \mathrm{s}$.

\section{Structures of Roncador Micro Hydroelectric Plant}

\section{A. Dam}

The dam should raise the level of the river, allowing the drowning of water intake. Souza, Fuchs and Santos (1983) emphasize that the dam must meet two conditions: to be stable in any condition and present degree of tightness consistent with its goals.

The dam of Roncador Hydroelectric is the wall-gravity type of concrete, on the basis of stones. It is presented in good work condition and has the following dimensions: Height: $2.57 \mathrm{~m}$; Width: $58 \mathrm{~m}$; Crest: $0.55 \mathrm{~m}$.

\section{B. Spillway}

According to Souza (2009), the spillway is constructed with the aim of disposing the excess of water accumulated
The water intake is intended to catch water, lead to the adductor system and from there to the hydraulic turbines. It should prevent the entry of floating bodies that could damage the turbine (SCHREIBER, 1977).

The water intake of Roncador hydroelectric is directly linked to the penstock, there is not pipe adduction at low pressure in this hydroelectric. The structure is able to use and its dimensions are $1.2 \mathrm{~m}$ wide and $3.5 \mathrm{~m}$ high.

\section{Penstock}

The penstock is the structure that leads the water to the power house, can be connected to standpipe or equilibrium chimney, or directly connected to the water intake. At Roncador hydroelectric, the penstock connects directly the water intake to the power house, and at one point of the penstock there is an equilibrium chimney.

The design of the penstock system depends on the number of turbines, water discharge and the length of the pipe (BALARIM, 1996). The existing structure is badly damaged and must be completely redone. The dimensions of the existent structure are $0.70 \mathrm{~m}$ diameter and $225 \mathrm{~m}$ in length.

\section{E. Equilibrium Chimney}

This structure is intended to reduce the pressure oscillations which propagate through the penstock caused by the closing or opening of the turbine. According to Flórez (2014), the need for installation of an equilibrium chimney for small hydropower plants can be verified by equation (2). If: 


$$
\mathrm{L}_{\mathrm{cf}} \geq 5 * \mathrm{H}_{\mathrm{b}}
$$

where $L_{c f}$ is the penstock length $[\mathrm{m}]$ and $\mathrm{H}_{\mathrm{b}}$ is the gross head $[\mathrm{m}]$.

Whereas the penstock length of Roncador is $225 \mathrm{~m}$ and the gross head is $14.8 \mathrm{~m}$, equation (2) indicates the need for installation of a equilibrium chimney in Roncador hydroelectric. The current structure has a diameter of 3.03 $\mathrm{m}$, a height of $6.85 \mathrm{~m}$ and it is $35 \mathrm{~m}$ away from the power house.

\section{F. Power House}

The power house is intended to house the machines and equipment, enabling its assembly and eventual disassembly, operation and maintenance (SCHREIBER, 1977).

The existing facility has approximately $75 \mathrm{~m}^{2}$, but is fully degraded, requiring entirety revitalization. Currently there is not equipment inside the power house. The study implementation includes the installation of four different types of turbines and generators. The turbines chosen for the study were: Banki, Pelton, Francis and Propeller.

\section{G. Tailrace}

The tailrace is the structure that returns the water to the river, after passing through the turbine (Eletrobrás and DNAEE, 1985). Souza (2009) explains that the objective of the tailrace is to reduce the kinetic energy of the water to values that prevent erosion across the discharge region.

The tailrace should be completely rebuilt and an escape channel for each turbine installed in the power house.

According to Alves (2007), the tailrace channel dimensions, width and depth are calculated by equations (3) and (4)

$$
\begin{gathered}
L=(0,1 * Q)+1,3 \\
C=(0,05 * Q)+2,3
\end{gathered}
$$

Where $\mathrm{L}$ is the depth $[\mathrm{m}], \mathrm{C}$ is the width $[\mathrm{m}]$ and $\mathrm{Q}$ is the flow rate $\left[\mathrm{m}^{3} / \mathrm{s}\right]$.

\section{Sizing of Structures to be Rebuilt}

\section{A. Penstock of Multiple Output}

By deploying four types of turbines in the micro station it becomes necessary to construct multiple outputs of the penstock

In a study by Stahlhoefer (2013), the penstock has a certain diameter to the level of the power house, referred to as unit segment, then branches into conduits of smaller diameters according to the number of machines, touted as the branched segment. The economic diameter of these segments was obtained by comparing the conduct of the construction costs and revenues left to raise due to loses of load.

Using a flow rate of $0.9 \mathrm{~m}^{3} / \mathrm{s}$ for the unit segment and a flow rate of $0.45 \mathrm{~m}^{3} / \mathrm{s}$ for the branched segment, the results shown in Figures 1 and 2 (Stahlhoefer, 2013).

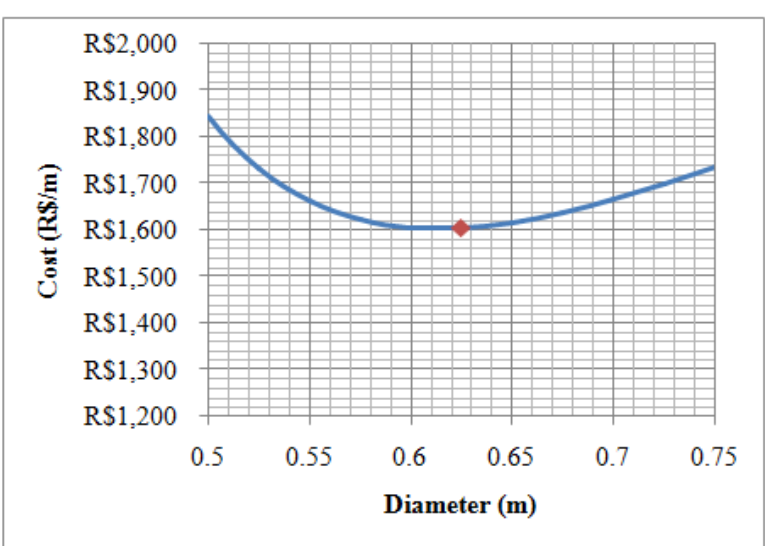

Fig. 1. Diameter of penstock - unit segment (Stahlhoefer, 2013).

It follows that for the unit segment the diameter is 625 $\mathrm{mm}$ and the branched segment diameter should be 450 $\mathrm{mm}$.

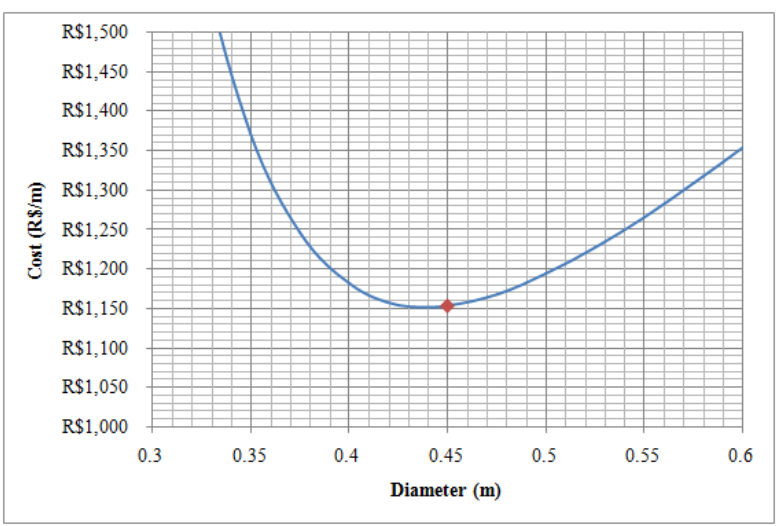

Fig. 2. Diameter of penstock - branched segment (Stahlhoefer, 2013).

\section{B. Power House}

The preliminary design of the power house was made after the design of turbines to be installed, according to NBR 12591 of 1992. Figure 3 shows the most detailed sizing of the penstock near the engine room and the layout of the turbines in it.

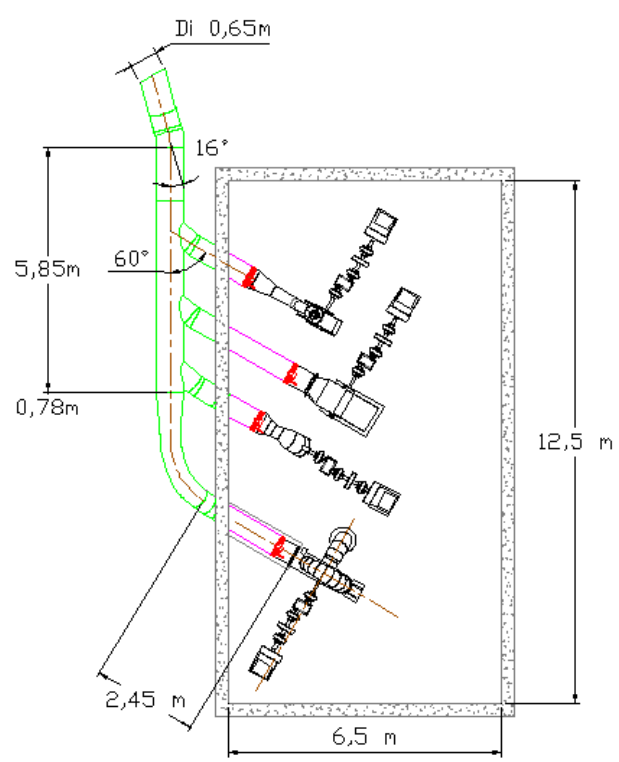

Fig. 3. Power House (Stahlhoefer, 2013). 


\section{Results}

It was observed that the reservoir has been suffering a siltation due to loss of soil accumulated caused by erosion occurring by the reduction of riparian vegetation, being necessary to carry out desilting and dredging in the reservoir. In the dam and spillway was observed small problems of erosion and loss of plaster, in this case a reform may leave the structures in working order.

According to a survey done in the hydroelectric, the penstock is no longer in use conditions, requiring the entire reconstruction of the structure. As the micro station will have at its plant four different turbines, was necessary to accomplish a study to the penstock with multiple outputs. In the power house, has been checked the need for total reconstruction of the structure. In the power house study were not considered facilities for the operator. The preliminary design was carried out through the design of turbines to be installed, but only after the choice of manufacturers will be held the final structure of the engine room.

According to studies, the micro hydroelectric has a regular flow of $0,450 \mathrm{~m}^{3} / \mathrm{s}$ delivered the turbine and a gross head of $14.8 \mathrm{~m}$. For this flow and fall, it was observed that the best turbine would be used is Francis turbine horizontal axis. However, the reactivation of the hydroelectric includes the installation of three other types of turbine: Pelton, Banki and Propeller.

\section{Final considerations}

The paper aims to contribute to the study of small and micro hydroelectric, which currently have very important due the evolution of technologies, recognizing its advantages and especially the promotion of sustainable development. The initial study to carry out this type of search is to obtain a suitable place for energy use, which does not result in major environmental impacts and impacts the surrounding community. In the case studied, the structures that can have an impact, such as dam construction, are already implemented, requiring only minor reforms.

\section{References}

[1] ALVES, Gilberto M. Avaliação da viabilidade de aplicação de uma microcentral hidrelétrica, para atender consumidores localizados em regiões isoladas. 2007. $156 \mathrm{f}$. PhD Thesis - São Paulo State University, Botucatu, 2007.

[2] _ NBR 12591: Dimensões principais de turbinas hidráulicas para PCH, 1992.

[3] BALARIM, Carlos R. Avaliação expedida do custo de implantação de microcentrais hidrelétricas. 1996. 162 f. Master's thesis - São Paulo State University, Botucatu, 1996.

[4] BEN - Balanço Energético Nacional (2014, ano base 2013). Available at:

<https://ben.epe.gov.br/downloads/S\%C3\%ADntese\%20do\%20R elat\%C3\%B3rio\%20Final_2014_Web.pdf> Access: 27 May 2014.

[5] DIAS, Marcos V. X. Geração Distribuída no Brasil: Oportunidades e Barreiras. Master's thesis - Graduate Program of the Federal University of Itajubá. Itajubá, 2005.
[6] ELETROBRÁS. DEPARTAMENTO NACIONAL DE ÁGUAS E ENERGIAELÉTRICA. Manual de microcentrais hidrelétricas. Rio de Janeiro, 1985.

[7] FLORÉZ, Ramiro O.Pequenas Centrais Hidrelétricas.São Paulo: Oficina de Textos, 2014.

[8] SCHREIBER, Gerhard P. Usina Hidrelétricas. São Paulo: Edgard Blücher; Rio de Janeiro: Engevix, 1977.

[9] SOUZA, Zulcy de; FUCHS, Ruvens Dario; SANTOS, Afonso H. Moreira. Centrais hidro e termelétricas. São Paulo: Edgard Blücher; Itajubá-MG: Federal School of Engineering, 1983.

[10] SOUZA, Zulcy de; SANTOS, Afonso H. M.; BORTONI, Edson da C. Centrais Hidrelétricas - Implantação e Comissionamento $-2^{\circ} \mathrm{ed}$. Rio de Janeiro: Interciência Ltda, 2009.

[11] STAHLHOEFER, Marcelo. Estudos Econômico para Repotencialização da Micro Central Roncador. 2013. Work Completion of course (Graduation) - Course of Mechanical Engineering. Federal Technological University of Paraná, Curitiba, 2013. 